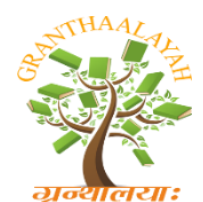

INTERNATIONAL JOURNAL OF RESEARCH GRANTHAALAYAH A knowledge Repository

Social

\title{
DIFFICULTY OF TEACHER IN IMPLEMETING THEMATIC LEARNING IN BASIC SCHOOLS IN MERAUKE PAPUA
}

\author{
Markus Palobo *1, Yonarlianto Tembang ${ }^{2}$ \\ ${ }^{* 1}$ Department of Mathematics Education, Musamus University, Indonesia \\ ${ }^{2}$ Department of Elementary School Education, Musamus University, Indonesia
}

\begin{abstract}
The purpose of this study was to describe the difficulties that were attended by elementary school teachers in Merauke district in implementing thematic learning based on the 2013 curriculum. This research was motivated by elementary school teachers in helping thematic learning in the learning process, as well as to learn things that were the result of difficulties teachers and solutions to overcome existing problems. This type of research is a qualitative descriptive study. The subjects in this study were 22 elementary school teachers in Merauke and 5 school principals. The data collection technique used in this research is by transferring questionnaires to each school, interviewing together with the teacher, and documenting the application of thematic and learning tools. The analysis in this study contains data reduction, data presentation and conclusions. The results of this study obtained data on elementary school teachers in Merauke district as a theoretical understanding of the implementation of the 2013 curriculum, but still lacking in making learning devices. These are the difficulties that form the basis of this research, namely; (1) development of indicators; (2) determine learning objectives based on indicators; (3) learning / methods / strategies and learning models; and (4) compiling assessment instruments. Based on the results of this study, it can be concluded that teachers still desperately need training to prepare learning devices and innovative learning models.
\end{abstract}

Keywords: Difficulties; Implementing Thematic Learning.

Cite This Article: Markus Palobo, and Yonarlianto Tembang. (2019). "DIFFICULTY OF TEACHER IN IMPLEMETING THEMATIC LEARNING IN BASIC SCHOOLS IN MERAUKE PAPUA." International Journal of Research - Granthaalayah, 7(11), 85-95. https://doi.org/10.29121/granthaalayah.v7.i11.2020.336.

\section{Introduction}

Education is a facility that is considered as a part of people is capital or a very large investment in the development of the current era. Guidance in education makes the current government able to develop an education that can foster creativity and innovation in learning. This is in accordance with the changes that have been made by the government in the past five years by seeking a curriculum that can change all learning that can attract students' interest and desire to learn [1]. At 
present the government is working on the 2013 curriculum to become a solution to improve the quality of education in Indonesia. In Indonesia the new curriculum introduced in 2013 replaces the previous curriculum, namely the education unit level curriculum is a major part of improving the quality of education.

The implementation of the 2013 curriculum is a learning process that applies thematic learning which refers to the development of the concept of an integrated approach. The integrated approach begins with an interdisciplinary concept that emphasizes integrated overall. This integration can be achieved through a combination of subjects centered on a problem and can be solved through themes that emphasize an event to find and direct a solution in that learning. Thematic learning has been carried out since the education unit level curriculum, but it is mandatory for its implementation in 2013. [2] Thematic implementation of the tertiary unit level curriculum is more focused on students' knowledge and skills and this is directed at low grade one students to third grade, while fourth grade students until the sixth grade has entered the subject. This is sought by the government at this time so that the implementation of the 2013 curriculum is not only in the two aspects but a solution so that learning can run well with the planting of attitudes to students. [3] Integrated thematic learning is learning by combining several subjects through the use of themes, students no longer learn the subject matter separately but all the subjects in the elementary school have merged into one learning activity which is tied into one theme, suggesting that learning V (ex-RSBI and accredited A) from only a few provinces, this curriculum is expected to be carried out thoroughly in schools in 2018 [4]. But in fact in 2018 the Ministry of Education and Culture even delivered the target number of those who had implemented the 2013 curriculum in $2017 / 2018$, only $40 \%$ of the total schools had implemented the 2013 curriculum. Only increased by $35 \%$ from 2016 . This was influenced by budget problems that have not been properly channeled, distribution of learning books that support this implementation and readiness of educators in this implementation [5]. [6] Based on these problems, which must be the basis of improvement, the teacher as the channeling of messages to students is a key to success in the implementation of the curriculum that will be implemented in each school throughout the country.

The city of Merauke itself is an area that can be categorized as a lagging, foremost, and outermost area that is located in the southern part of Papua which is directly adjacent to Papua New Guinea [7]. But the government basically wants to advance human resources in the education sector. The efforts that have been made by the government now starting from 2017 to the present continue to implement the 2013 curriculum so that it can be well-isolated to each of the schools in Merauke district. According to in 2017 there were only 2 out of 60 primary schools implementing the 2013 curriculum in Merauke Regency, the primary school was the Gudang Arang Inpres elementary school and the Polder Inpres elementary school. Where the two schools are pilot schools located in Merauke district in 2017 [8].

Based on data from the Ministry of Education and Culture in the 2018/2019 school year, there are 34 primary schools in Merauke sub-district, consisting of 14 public schools and 20 private schools. Based on these data, it can be seen that almost all elementary schools in Merauke district have implemented the 2013 curriculum in accordance with the direction of the central government that the 2019/2020 school year is implementing the 2013 curriculum. Taking into account the basic concepts of the 2013 curriculum in developing student character and implementation in life culture in the community later. This curriculum is very helpful and accelerates the development especially 
in Merauke Regency itself in preparing to become a food economic zone that has been planned by the government now, as a city with several border countries that must be able to become a pillar that can support Indonesia in the border region [8].

Even though there is a lot of controversy on the implementation in a number of schools and worrying about teacher submission, because there are still many teachers who do not understand the essence of curriculum changes and re-request the 2006 curriculum, they are not yet ready to implement the 2013 curriculum. it can be implemented well, not a matter of debating the budget but the active role of each executor in the successful implementation of the 2013 curriculum implementation. In any country, even though technology has become an integral part of the world of education, the role of the teacher in the learning process remains a word the key to the success of education. Preparation of teachers in dealing with changes to this curriculum must be very concerned. Are teachers ready to face curriculum changes or not yet, don't let the curriculum change but the teacher's mindset to implement the curriculum has not changed [9]. The teacher's mindset cannot change according to its function as a transformer and facilitator for its students. The teacher as a transformer means being able to do the best that is able to develop abilities in accordance with his profession, the teacher as a facilitator then he provides convenience or facilitates students in learning so students can more easily understand what has been said and grow the spirit of students in learning, and become an example for students in fostering character and action.

Based on the description of the above problems, this study was conducted to describe the difficulties of teachers in implementing thematic learning in primary schools in Merauke district, namely by analyzing planning, implementation and evaluation both theoretically and practically. The purpose of this study is to describe the difficulties of teachers in the future of thematic learning especially elementary school teachers in the implementation of the 2013 curriculum.

\section{Methods}

This research is a descriptive qualitative study that analyzes and describes the conditions and facts in the field during the research process which are explained through descriptive words. This study aims to determine the role of teachers, learning planning, curriculum documentation, constraints and solutions to overcome the problems that occur in thematic learning in elementary schools in Merauke City. This research was conducted in the city of Merauke with a total of 34 schools. The subjects to be studied are 22 schools, the selection of schools is based on the consideration that there are still many schools that have not implemented the 2013 curriculum well and information from each school principal when distributing questionnaires to schools not yet willing to provide data because the school has not implemented the 2013 curriculum and has not once compiled learning devices like thematic.

The research instrument used in this study was a questionnaire of difficulties in preparing an open and closed implementation plan. Questionnaire consists of 3 points or main parts, the first is related to the components and systematics of learning implementation plans, the second part is the development of learning implementation planning and the third part is the 2013 curriculum implementation aspects. Questionnaire consists of 42 closed questions and 43 open questions. The data collection technique in this study was through the distribution of questionnaires in each school 
about the difficulties of the teacher in applying thematics in elementary schools as many as 22 subjects and explained how the teacher filled out the questionnaire sheet. Interviews in this study were class teachers who had implemented the 2013 curriculum and several school principals related to the questionnaire that had been filled. Documentation is done by collecting written documents that are in accordance with the focus of research on supporting data from interviews, observations, and questionnaires so that they can be recognized as valid. Documents needed in this study are school profiles, learning tools, evaluation results, and photos of activities during learning.

Data collected in this study is descriptive qualitative data by distributing questionnaires containing questions to 22 elementary schools in Merauke district in the form of closed questions and open questions. The research instrument used in this study was tested using a triangulation test to find out whether the instrument used was in accordance with the focus of the study. Data analysis techniques in the study using Miles and Huberman namely; (1) data reduction; (2) data presentation; (3) drawing conclusions from the analysis [10]. The data reduction phase summarizes all the data that has been obtained, sifts through important data, and determines unnecessary data to be discarded. Data presentation is used to organize data so that data is easier to understand. This research will present data in the form of a description of the preparation and implementation of thematic learning in elementary schools in Merauke district. Data verification is a conclusion of the data that has been obtained. In general, the procedure in this study is divided into three parts, namely; data preparation, implementation and analysis.

\section{Results and Discussions}

\subsection{Results}

Based on research analyzing the difficulties of teachers in the application of thematic learning in elementary schools which is the first step in developing the quality of education in Merauke there are several difficulties including, (1) the components and systematics of the implementation of thematic learning plans, (2) development of learning implementation plans thematic, (3) aspects of the implementation of thematic learning. Preliminary studies were carried out by mapping several schools that had implemented thematic learning and then conducted interviews to find out the existing descriptions in each school according to the focus of the study. This initial observation was carried out to find out how to develop learning devices in accordance with core competencies and basic competencies.

\subsubsection{Components and System of Mathematics Thematic Learning Implementation Plan}

Data obtained based on questionnaires and interviews with elementary school teachers showed that all teachers in Merauke district based on a sample of 22 elementary schools stated that the questionnaire had been arranged in accordance with the learning plan and in accordance with the systematics set in the 2013 curriculum. , the teacher already has an understanding of how to develop a learning tool obtained through training conducted by the local government to improve the quality of education available in Merauke district. The speakers used in the training were 2013 curriculum expert presenters who truly had the ability to develop learning tools as well as presenters from the provincial level who were sent by the district government and often also invited presenters from the center. The results of the implementation plan of learning that is owned by 
each teacher in plain view is in accordance with the systematic writing of learning devices that are in accordance with the system regulated by the ministry of culture which becomes a reference for the teacher to compile the device.

The second question written on the questionnaire on the level of difficulty of the teacher in compiling a learning tool consisting of 21 questions in accordance with the components of the learning implementation plan found that all teachers can categorize very easily in compiling components of school identity, core competencies, basic competencies, initial activities, and activities closing learning. These components are components that are relatively the same as the previous curriculum, where core competencies and basic competencies are components that already exist and have been set nationally for all learning content, even now there are nationally uniform indicators of competency achievement, just adjust with the characteristics of their students. Components of material description, media / learning tools, learning resources, time allocation in meetings, apperception activities, scientific application, student worksheets, direct learning objectives, learning outcomes assessment techniques, are considered teachers in the medium category to be arranged in a learning implementation plan. The emphasis on the 2013 curriculum which is more pressing on scientific learning is considered to be very important because the $5 \mathrm{M}$ activities that distinguish the previous curriculum. As for the other components, the teacher is considered as a component that is often carried out by the teacher and almost the same as the previous curriculum.

The learning implementation plan is categorized as difficult for teachers, namely indicators of achievement of competencies, learning objectives, approaches / methods / strategies of learning and assessment instruments. The indicator component of achievement of this competency is considered difficult by the teacher because it has to develop an indicator based on the basic competencies that exist in each material, the teacher also does not understand how the teacher uses operational words which can be easier to describe each activity that will be related to the learning objectives later. Operational words used in competency achievement indicators must refer to the bloom taxonomy which is divided into 6 dimensions, namely remembering, understanding, applying, analyzing, evaluating, and creating this thing which is considered difficult by teachers to describe indicators of competency achievement based on basic competencies. The component of learning objectives is the development of indicators of achievement of competencies which greatly influence what is obtained based on indicators. The learning objectives developed by the teacher so far do not refer to the predetermined aspects based on the questionnaire that is given by the teacher is still very difficult to examine what must be written on the learning objectives. Teachers mostly develop learning goals seeing from the sharing of references that exist even from some of the results of interviews from school teachers say most learning objectives are developed by looking at those already on the internet and then transferred into prepared learning devices. This is the reason the teacher says it is difficult to develop learning goals.

Approach/method/strategy is a very difficult component which is considered by many teachers based on interviews from several school teachers saying that it is not easy to determine a method/strategy without regard to the social character of students because this is related to psychostudents who are guided can develop and find out what has been learned and applied in the student. This 2013 curriculum emphasizes the scientific approach where some teachers in some schools are still very unfamiliar in applying 5M, advice that some teachers have delivered from the school has 
systematic training from the relevant agencies to be able to understand each of the $5 \mathrm{M}$ stages so that they are truly implemented and the teacher also not confused in the implementation, implementing or giving examples to be able to understand well according to existing regulatory guidelines. The learning methods and strategies used are also different from the previous curriculum so that the teacher must really adapt to the new methods, models and strategies because there are many new learning models that have never been done in the previous curriculum so that the teacher is very difficult in determining methods, models and strategies learning.

Instrument assessment which is the last question filled by the teacher based on these results from several schools the teacher categorizes that the assessment instrument in the category is difficult to do, the reason for the teacher because it is very complicated and requires a very long time, starting from describing each aspect and developing each ability has been obtained by students. The assessment of the three aspects requires an instrument that must be arranged by the teacher according to the theme that has been taught and related to the teaching material in the plan for implementing the learning. Based on interviews from several schools the teacher's assessment said that the preparation of assessment instruments became obstacles that were considered by teachers to be very difficult to develop considering that each aspect was divided into 3 aspects of assessment, namely cognitive, affective, and psychomotor which made it very difficult for teachers to describe each aspect. For the cognitive aspects of the teacher, it is not very effective because remembering so far, the teacher has been accustomed to developing aspects of the cognitive domain in accordance with the previous curriculum.

\subsubsection{Development of Thematic Learning Implementation Plans}

The development of the implementation plan for thematic learning in primary schools in the second part asks about the preparation of basic competency mapping plans, establishing theme networks, developing material based on apperception, and closing learning strategies. The four questions in section 2 are an attempt to find out the level of teacher understanding in thematic learning. Questions about basic competency mapping according to teachers have been very common because this has already been done in the previous curriculum, where the previous curriculum has applied thematically to low classes only while the new curriculum for grades 1-6 is implemented using themes. The thing that is considered by the teacher is difficult to do is the elaboration of core competencies and basic competencies of each subject into the indicator. Here the teacher adjusts a lot to the previous curriculum by developing from basic competencies without making a determination whether this predetermined basic competency will be in accordance with the indicators which will later become the basis of reference in determining learning objectives. There are several teacher schools saying that it is very difficult to determine and formulate indicators into operational words. As determined by the Ministry of Education and Culture, the teacher also has difficulty in interpreting indicators according to the level of interest whether it is a support of basic competencies. But there are 5 schools that say that it is not new to develop indicators based on basic competencies by adapting learning theories from the taxonomy of bloom. Determine the theme.

Based on the component of determining the theme in thematic lessons the teacher categorizes it easy to write because the theme in the 2013 curriculum thematic learning already has a format on the teacher's book and is written into one thematic integrated learning based on graduate 
competency standards and translated into core competencies. What teachers consider difficult to understand is the mapping of basic competencies in each subject. In accordance with the research conducted by[11], which states that teachers are still experiencing difficulties in integrating content and teaching in the theme of the subject is still very difficult for some teachers in the Central Java branch of the Kanisius Foundation in Yogyakarta. The teacher is not yet familiar with basic competency mapping because in the previous curriculum the basic composition only has 1 basic competency while in the 2013 curriculum the basic competencies in each subject can reach 3-4 contained in the broad basic competencies in the subject according to the indicators which will be produced later. Determination of basic competencies is important in preparing learning devices because there are cognitive and psychomotor aspects of students in each subject, this is what the teacher must really understand in determining aspects according to the needs of students in the classroom. Teachers, teachers are not only take in the teacher's book but how to know what will be poured and implemented to the students later. As for one of the basic competency assignments from several teacher schools, it is difficult to understand, namely the theme of the objects in the surrounding environment can be seen in this picture.

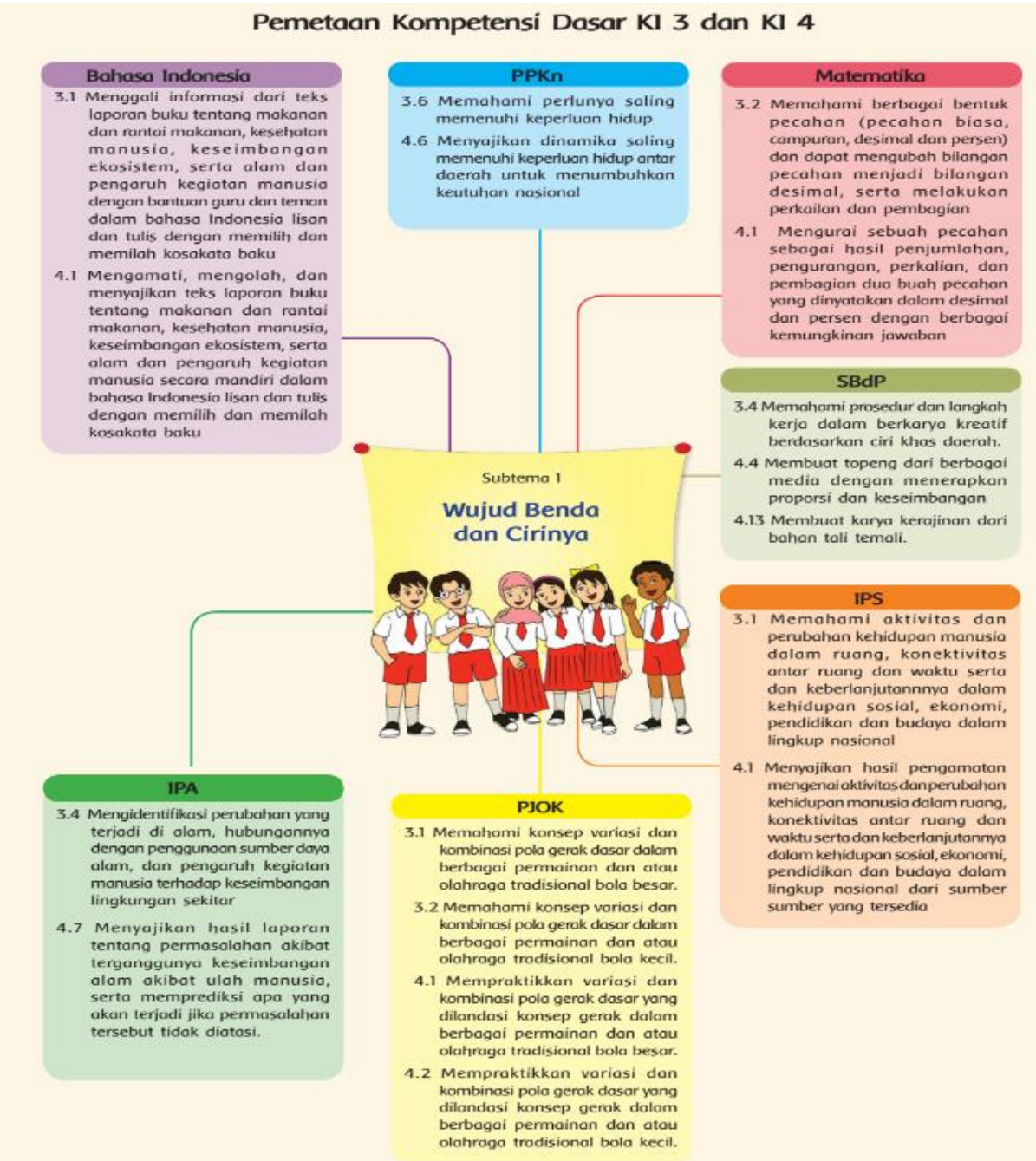

Figure 3: Mapping of Basic Competencies 
Based on Figure 1 it can be seen that there are several basic competencies in 1 sub-theme[12]. Most teachers understand that when drawing up a plan for implementing basic competency learning that exists in basic competency mapping, it is only necessary to take from each of the basic competencies one by one and then enter into the learning implementation plan. The teacher should first understand each content in the lesson that will be integrated into the learning implementation plan so that it is easier to develop in accordance with the expected graduate potential. Identifying and analysing the basic competencies that have been determined and then chosen by one theme that is in accordance with the learning that will be carried out is a task that must be done by the teacher because by determining the basic competencies in accordance with these will determine the achievement of the expected learning goals.

The final component in this question is the strategy to close learning. According to some schools the teacher said that drawing conclusions at the end of learning is very necessary to transfer and check the students' memory and the seriousness of learning. There are also some opinions from other schools saying that the strategy of closing the lesson is a strategy where the teacher repeats and concludes the material at that time together with the students so that the teacher not only teaches but is right to know that what is delivered is truly left to the mind of the student and is always remembered. Another opinion said that activities draw important conclusions for students to know the main ideas of the material that must be achieved. The teacher's strategy in developing conclusions is to instruct students to deliver the material that has been taught to each, the students mention then the teacher writes the written board of the results that have been delivered then gives questions to students and gives rewards at the end of learning to foster student enthusiasm in closing learning. There is also a strategy carried out by the teacher by giving questions about changing individual questions to students then students working on the questions for follow-up reminding the next material and giving homework to students for follow-up on the next activity. Based on the component of the strategy question closing learning from several schools said that the difficulties experienced by the teacher were analyzing the material, difficulties in the ability of students to remember the material that had been taught, and determine effective methods in accordance with the material being taught.

\subsubsection{Implementation of Thematic Learning}

The implementation of thematic learning is the third part of the teacher's difficulty questionnaire in the application of thematic learning in elementary schools. The questions about the part of thematic learning in the 2013 curriculum that are the most difficult to implement based on the first question component of the sample of 22 schools all uniform that difficulties are from the assessment. Nearly all schools say that a very detailed assessment process requires extra thinking to calculate a lot of waste of time and energy that should be used to carry out other work related to school work. Whereas the second problem that was conveyed from several schools of teachers said that scientific implementation had not been implemented well. Scientific activities that emphasize 5 aspects of activities, namely, observing, asking, trying, reasoning, and communicating are things that are difficult for teachers to do in the classroom, based on interviews with the principal saying that most teachers develop a thematic learning plan according to the 2013 curriculum format, but in its implementation sometimes the teacher ignores this by still using the old curriculum because the teacher feels very familiar in applying the old curriculum rather than applying the new curriculum thematically. The teacher also said especially in the activity of 
communicating and reasoning. This is considered difficult by the teacher because there are not all students' understandings that are slow to reason and some are quick to reason, which is often a barrier when the teacher applies this activity.

Besides that the teacher is also very difficult in updating the learning models that have been guided in the 2013 curriculum to be included in the thematic learning implementation plan where one example of the learning model is inqury based learning and project based learning, from the two learning models there are still many teachers who do not understand in each learning syntax and when the researcher asks the teacher whether the teacher has applied this model, the teacher said that he never implemented implementing this model and from several schools the teacher said that it was still very strange to listen to the model. Based on the component of the question and the interview with the teacher, it can be concluded that the learning model is still very little mastered because the syntax of learning according to the teacher is complicated, even some schools say it is still comfortable using the old learning model because it is not complicated with the student syntax to listen to what is said by teachers and students working on it.

\subsection{Discussion}

Based on the research of teacher difficulties in the application of thematic learning in elementary schools, there were several types of difficulties experienced by teachers in implementing thematic learning in elementary schools. unfavorable and inconsistent results. In general, the components of the learning implementation plan are the most difficult to be developed by elementary school teachers in Merauke district, namely indicators of competency achievement, learning methods / approaches / strategies in core activities, closing activities or closing strategies, and assessment instruments. The same thing was experienced by teachers in several cities in Indonesia. Starting from the preparation of the learning implementation plan until its implementation in the teacher class is still very difficult to implement. Difficulties of some teachers in indicator development activities Achieving basic competencies is the difficulty in choosing the right operational words according to the guidelines required in the 2013 curriculum using a theory from the taxonomy of bloom. The selection of operational words for indicators of achievement of competencies requires a deep understanding of the teacher about the demands of basic competencies, so that they can be described in the indicators. In addition, the teachers also felt difficulties in describing indicators according to their level of importance, whether it was urgent or supportive. This means that elementary school teachers still have difficulty determining the most important indicators of basic competencies given. The 2013 curriculum requires indicators of achievement of basic competencies in aspects of attitude [13]. Thus, the teacher must be able to formulate attitude indicators that must be met by students in basic competencies.

The difficulty experienced by elementary school teachers in Merauke Regency is to develop a scheme for achieving basic competencies, including difficulties in analyzing material concepts that must be harmonized with the approach used, different levels of students' abilities, indicating that there is a need for in-depth analysis of teaching material so that the scheme for achieving basic competencies can be developed properly. The approach that has been put forward by the government today is to penalize the learning process that emphasizes the application of the concept of learning while doing something. Therefore, teachers are guided to be able to design and implement learning experiences that link conceptual elements to effective learning. Conceptual 
linkages with thematic learning learned will form a scheme, so that students will gain more knowledge integrity. The development of apperception activities / material from several teacher schools has difficulty in determining the compatibility between the material to be studied and its apperception. Apperception activities are very important in connecting the previous material with the material to be studied, while providing the initial steps for students to transfer their abilities by finding links to learning to be learned and providing motivation for students about the importance of teaching materials so that teachers need to develop apperception strategies for students keep linking each teaching material provided. Another difficulty faced by teachers is that linking each material that will be taught before and after being taught students still do not understand and students are so easy to forget what has been said before. Based on the interview in one of the schools the teacher said that students quickly forgot the material previously taught to want to enter the material later the teacher again repeated the previous material. For this reason, the teacher should give a question at the end of the lesson so that students can follow up on the material obtained on that day in the form of homework.

Approaches / methods / strategies and models are included in the core learning activities that become a component of learning, namely the steps of learning. The steps of learning have preliminary activities, core activities and final activities in this study based on core activities contained in them how the teacher can describe in detail the approaches / methods / strategies and predetermined models the difficulties teachers get here are that the teacher has not been able to describe in every detail of learning activities, the teacher also feels very schooling with the latest learning models with so many syntaxes and steps in each model. Another difficulty obtained from several schools is the development of learning activities that guide students to be actively involved and the classroom atmosphere to come alive. In general, it is a very difficult part for the teacher because it requires the proper selection of learning models to be easily understood by the teacher so that the expected learning atmosphere in this activity can be achieved well. In the final activity in this learning device is the final activity or closing activity of learning, the activity of closing the 2013 curriculum-based learning is how the teacher manages the time so that the activities to close the learning can be carried out properly. This activity is not carried out optimally because this activity is an activity that is at the end of learning and is usually not implemented because remembering the time will end based on the results of interviews with one school. For this reason, the timing of the closing activities should be considered carefully by the teacher, the teacher is not just writing time in the closing activities, because this activity is very influential on the final conclusions obtained by students later.

The difficulty that is the biggest scourge for elementary school teachers in Merauke district is to compile an assessment. For this reason, there should be trainings given from related agencies to develop assessment instruments which are a great difficulty for teachers in giving assessment to students, the same thing is also stated by [9]. It is expected that the training carried out to teachers related to 2013 curriculum and supporting facilities, facilities and infrastructures in implementing the 2013 curriculum. The teacher also hopes that the format that remains in accordance with the planned implementation of learning does not constantly change because it can make it difficult for teachers to adapt to new things. 


\section{Conclusions and Recommendations}

The difficulties experienced by elementary school teachers in Merauke district in compiling thematic learning tools in accordance with the 2013 curriculum, namely; (1) development of indicators: (2) determination of learning objectives based on indicators; (3) determine the approach / method / strategy and learning model; and (4) preparation of assessment instruments. The teacher really hopes that the policy makers and related agencies can provide training and pay attention to the difficulties experienced by teachers especially in compiling and implementing thematic learning in elementary schools

\section{Acknowledgements}

Thank you to the Indonesia Ministry of Research, Technology and Higher Educatian and who have financed this, as well as the principal and teachers of Merauke as participants of this research.

\section{References}

[1] Rosmah S, Tindangen M and Rambitan V M 2018 Analisis Permasalahan terkait Kebutuhan Pengembangan Perangkat Pembelajaran Model Discovery Learning untuk Meningkatkan Pemahaman Konsep dan Sikap Ilmiah J. Pendidik. Teor. Penelitian, dan Pengemb.3 322-4

[2] Sari N A, Akbar S and Yuniastuti Y 2018 Penerapan Pembelajaran Tematik Terpadu di Sekolah Dasar J. Pendidik. Teor. Penelitian, dan Pengemb.3 1572-82

[3] Kemendikbud. 2013 Kerangka Dasar Kurikulum 2013. Kementerian Pendidikan dan Kebudayaan Direktorat Jenderal Pendidikan Dasar (Jakarta)

[4] Mulyasa. H. E. 2016 Pengembangan dan Implementasi Kurikulum 2013 (Bandung: Remaja Rosdakarya)

[5] Alawiyah F 2015 Kesiapan Guru dalam Implementasi Kurikulum 2013 Kaji. Singk.VI 9-11

[6] Ruslau M F V. and Meirista E 2017 Analisis Biplot Untuk Pemetaan Kebutuhan Guru Di Kabupaten Merauke Magistra J. Kegur. dan Ilmu Pendidik.4 1-14

[7] Santo Z and Hidayat A K 2018 Pengembangan Senam Baca Hitung (Catung) Bagi Siswa Sekolah Dasar Sota Perbatasan RI-PNG) 5 38-47

[8] Hurit A A and Harmawati D 2019 Analisis Kesiapan Guru dalam Mengimplementasikan Kurikulum 2013 di SD Inpres Gudang Arang Merauke primay Educ.1 116-23

[9] Kristiantari R 2014 Analisis Kesiapan Guru Sekolah Dasar Dalam Mengimplementasikan Pembelajaran Tematik Integratif Menyongsong Kurikulum 2013 J. Pendidik. Indones.3 460-9

[10] Sugiyono. 2017 Metode Penelitian Pendidikan Pendekatan Kuantitatif, Kualitatif, dan R\&D (Bandung: Alfabeta)

[11] Krisnandi and Rusmawan 2015 The Constraints of Elementary School Teachers In The Implementation Of The 2013 Curriculum Cakrawala Pendidik.Th. XXXIV, 457-67

[12] 2014 K P dan K R I 2014 Benda-benda di Lingkungan Sekitar (Jakarta)

[13] Palobo M, Sianturi M, I, Marlissa N, Purwanty R, Dadi O and Andi Saparuddin Nur 2018 Analysis of Teachers ' Difficulties on Developing Curriculum 2013 Lesson Plans 1st International Conference on Social Sciences (ICSS 2018) vol 226 pp 1319-24

*Corresponding author.

E-mail address: markuspalobo @unmus.ac.id 